\section{DOKTRIN SYI'AH DALAM MASALAH IMAMAH DAN FIKIHNYA}

\section{Muh. Said HM.}

Fakultas Syari'ab dan Imu Hukum UIN Suska Riau

\section{Abstract}

Syiah Doctrine in the Case of Its Imamah and Fiqh: The problem of Imamah during the death of the Prophet Mubammad saw became the serious political discussion in the Muslim society and his companions at that time. The central discussion was on who would replace bis position as the leader of Muslim community. This became the early political conflict in the bistory of Muslim society, and its ultimate conflict was during the Uthman Caliph. There were many conflicts, challenges, and even victims. There three main contestants involved, namely, Muawiyah, Khawarij, and Syiah (the followers of Ali bin Abu Thalib). In this case, Syiah Imamiyah Itsna 'Asyariyah related to its concept of imamah and fiqh has different doctrine compared to other sects.

Keywords: Syiah, Imamah and Figh.

\section{Pendahuluan}

Di awal sejarah dalam Islam, memberikan kesan yang mendalam, bahwa Islam sebagai agama, persoalan-persoalan teologinya menjad dominasi perdebatan sosial umat, menyebabkan berbagai aliran-aliran teologi dengan berbagai versi misi dan visinya bermunculan adanya. Sejalan dengan hal tersebut, tidak kalah pula hebatnya munculnya perdebatan-perdebatan social politik dikalangan umat dikemudian hari yang selalu menyertainya. Oleh karena itu menurut Harun Nasution adalah suatu keanehan bila kita mengatakan bahwa dalam Islam, sebagai agama, persoalan yang pertama-tama timbul adalah dalam bidang politik dan bukan dalam bidang teologi. Tetapi gara-gara
Muh. Said HM., Doktrin Syi'ah dalam Masalah Imamah dan Fikihnya persoalan politik iniah sesungguhnya segera meningkat menjadi persoalan teologi"'.

Munculnya perdebatan sengit dalam bidang politik, terutama sebelum bahkan setelah wafatnya Muhammad Ibn Abdullah dengan kapasitasnya sebagai seorang pemimpin agama (punya kekuasaan spiritual) sekaligus dengan kapasitasnya sebagai pemimpin politik, karena beliau tidak menjelaskan dan mewariskan ketegasan yang jelas dan pasti kepada umat dan para shahabatnya, khususnya yang berkaitan dengan kepentingan social umat dalam tatanan sistem imamah. Karena sebagaimana dipahami bahwa memang beliau sendiri menjadi kepala Negara (pemimpin pilitik) bukanlah atas dasar penunjukan dan pula bukan atas dasar hak turun temurun. Beliau sebagai Rasul secara otomatis menjadi kepala Negara. ${ }^{2}$ Menurut hemat penulis mungkin disisi lain ada hikmah dan mutiara yang tersirat dibalik itu semua mengapa Rasulullah Saw seolah-olah "sampai hati dan teganya" tidak memberikan taushiyah yang pasti dikalangan umat

${ }^{1}$ Harun Nasution, Teologi Islam, Aliran-aliran Sejarah, Analisa Perbandingan, edisi 5, (Jakarta: UI Press, 1986), hlm. 1

${ }^{2}$ Harun Nasution, Islam Ditinjan dariBerbagai Aspeknya, Jilid I, Jakarta : UI Press, 1979), hlm. 101. Dalam suatu riwayat dari Ali r.a. ia berkata: Rasulullah ditanya, Ya Rasulullah, siapakah yang akan menjadi pemimpin setelahmu ? Nabi Saw menjawab, Jika kamu menjadikan Abu Bakar sebagai pemimpin, maka kamu akan mendapatkan dia orang yang terpercava, zuhud dalam urusan dunia, dan senang kehidupan akhirat. Jika kamu mejadikan Umar sebagai pemimpin, maka kamu akan mendapatkan dia sebagai orang yang kuat, terpercaya, dan tidak takut kecaman siapapun dalam menjalankan hukum Allah. Dan jika kamu menjadikan Ali sebagai pemimpin, dan saya melihat kamu tidak akan melakukanya, maka kamu akan mendapatkan dia orang yang memberi petunjuk dan yang mendapatkan petunjuk, yang akan membimbingmu ke jalan yang lurus (baca : Musnad Imam Ahmad, Jilid V Nomor 859, syarah dan indeks oleh Ahmad Syakir, (Mesir: Da alMa'arif, t.th).

Keterangan tersebut memberikan indikasi bahwa sesungguhnya pemikiran tentang imamah telah muncul pada masa hidup Rasulullah Saw. namun baru hanya bersifat saran pilihan kepada para shahabat dan ummatnya. Oleh karena itu wajar, jika pada akhirnya perselisihan awal tentang khilafah itu terjadi setelah beliau wafat, dengan diadakannya pertemuan di Saqifah, yang diikuti dengan pembai'atan Abu Bakar r.a sebagai khalifah pertama. 
Al-Fikra: Jurnal Ilmiah Keislaman, Vol. 8, No. 2, Juli-Desember 2009

dan para shahabatnya, karena sebagaimana dipahami bahwa Rasulullah Saw jauh-jauh sebelumnya telah memberikan wejangan sosial bahwa "sebenarnya kalianlah yang lebih tahu ketimbang saya mengenai segala persoalan-persoalan kehidupan duniamu".

Yang pasti, bahwa perbincangan dan perdebatan-perdebatan social politik sebelum dan setelah Nabi Muhammad Saw. wafat, merupakan awal pertikaian politik yang amat serius dikalangan umat dan para shahabat (al-Khulafau al-Rasyidun) terutama. Pada akhirnya melahirkan teori politik yang pertama timbul dari perkembangan politik yang terjadi dalam sejarah Islam, yaitu mengenai jabatan kepala Negara (imamah). Berkisar siapa sebenarnya yang lebih pantas menggantikan Nabi Muhammad Saw dalam kapasitasnya sebagai pemimpin umat dan Negara, dan bagaimana pula sebenarnya cara-cara yang harus ditempuh dan sebagainya. Demikian seterusnya sampai kepada puncak pertikaian politik yang semakin lebih "panas" ketika derama kematian Utsman Ibn Affan (23-35 H/644-656 M) tiba pada gilirannya, yang pada akhirnya mengantarkan sosok Ali Ibn Abi Thalib (35-40 H/656-661 M) sebagai penggantinya menjadi khalifah ke empat, yang sesungguhnya juga tidak lepas dari pada pertikaian politik tidak kalah hebatnya, antara dukungan pro dan kontra dikalangan umat menyebabkan pertumpahan darah-pun tidak dapat terhindarkan, siapa sebenarnya mereka yang mati syahid di kala itu, hanyalah Allahlah yang Maha Mengetahuinya. Peristiwa berdarah lagi mengundang kematian itu, sesuai apa yang dikatakan oleh Al-Syahrastani bahwa "sesungguhnya pertikaian-pertikaian politik dan perselisihan umat Islam yang terbesar adalah perselisihan menyangkut persoalan imamah. Perselisihan tersebut mengakibatkan pertumpahan darah yang luar biasa dalam sejarah Islam, yang sebelumnya belum pernah terjadi"3.

Sejarah mencatat, bahwa sebenarnya sosok Ali Ibn Abi Thalib memang calon terkuat untuk menduduki posisi khalifah ke empat, setelah kematian Utsman (bahkan ketika wafatnya Nabi Saw, Umar

${ }^{3}$ Muhammad Abu Zahrah, Tarekh al-Mazahib al-Islamiyah, (Cairo: Dar al-Fikr al-'Araby, t.th), hlm. 21
Muh. Said HM., Dok.trin Syi'ah dalam Masalah Imamah dan Fikihnya

Ibn Khtthab mengakui bahwa Ali yang seharusnya menggantikannya). Karena kompetensinya luar biasa, hampir dalam semua peristiwa ghazwah yang dipimpin Rasulullah Saw, ia senantiasa berada didepan, bergulat atau perang tanding dihadapinya tanpa takut resiko maut. Sangat terkenal dengan keberaniannya yang luar biasa, ahli strategi dalam memimpin peperang, dengan pula dengan pribadi kezuhudan dan keluasan ilmunya. Ali terhitung salah seorang dari tiga tokoh utama (Abu Bakar, Umar dan Ali) yang telah mewarisi pengetahuan, budi pekerti dan kebersihan jiwa Rasulullah Saw. Bahkan Rasulullah Saw. sendiri berkata kepada Ali "anta akhiy fi al-dunyaa wa al-khirah"." Tetapi ketika itu, segera ia mendapat tantangan dan reaksi keras dari pemuka-pemuka lain yang ingin pula menjadi khalifah, terutama misalnya Thalhah dan Zubair dari Mekkah yang mendapat dukungan dari Aisyah. Dalam peperangan yang terjadi, menyebakan Thalhah dan Zubeir menemui ajalnya, mati terbunuh, sementara Aisyah dikirim kembali ke Mekkah.

Tantangan keras berikutnya juga datang dari Mu'awiyah, Gubernur Damaskus dikala itu dan anggota keluarga terdekat Utsman Ibn Affan. Mu'awiyah tidak mengakui sosok Ali sebagai khalifah menggantikan Utsman, bahkan ia menuduh Ali turut campur tangan dan terlibat langsung dalam soal kematian Utsman, karena salah seorang dari kaum pemberontak, yaitu Muhammad namanya, adalah anak angkat Ali sendiri. Antara ke dua golongan akhirnya terjadi peperangan yang luar biasa di Shiffin, Irak, kemudian disusul diadakan tahkim (arbitrase). Ali dalam hal tersebut terjebak menerima tipu meshlihat Amr Ibn 'Ash mengadakan arbitrase, sungguhpun dalam situasi dan kondisi terpaksa tidak disetujui oleh sebagian tentaranya. Kaum tentara yang tidak setuju ini mengasingkan diri dan keluar dari barisan Ali, mereka itulah yang disebut sebagai kaum Khawarij. Ali

${ }^{4}$ Muhammad Ridha, Al-Imam 'Ali Ibn Abi Thalib, (Beirut: Daar al-Kutub alilmiyah, t.th), hlm. 5-6, serta Ahmad Syalabi, Mausu'ah (al-Tarekh al-Islami wa alHadharah al-Islamiyah), edisi 7, Jilid I, (Masir: t.p, 1978), hlm. 439, dan bandingkan Abdul hasan Ali Al-Hasani An-Nadwi, Shuratani Mutadhadatani, terjemahan Bey Arifin, dkk. (Surabaya: PT. Bina Ilmu, 1988), hlm. 28 
A1-Fikra: Jurnal Ilmiah Keislaman, Vol. 8, No. 2, Juli-Desember 2009

Ibn Abi Thalib, akhirnya wafat pada tahun $40 \mathrm{H} / 661 \mathrm{M}$ dibunuh oleh salah seorang kelompok dari kaum Khawarij, disebabkan karena Al terus menerus menumpas mereka. ${ }^{5}$ Ketika itulah menyebabkan munculnya katakanlah tiga kontestan partai politik besar, yaitu golongan yang pro pada Ali itu sendiri disebut kaum Syi'ah, ${ }^{6}$ dan sebaliknya golongan yang kontra pada Ali disebut kaum Khawarij, serta golongan kaum Mu'awiyah (ahl al-Bait).

5 Harun Nasution, Islam Ditinjau ..., hlm. 94-95, bandingkan Abdul Mu’im Al-Nimr, Syi'ah, Imam Mabdi dan Durur, Sejarah dan Fakta, edisi 1, terjemahan Prof.Dr. Ali Mustafa Ya'qub, (t.t: Qisthi Press, 2003), hlm. 47

6 Kata "Syi'ah" secara etimologi adalah cinta, penolong, pengikut, dan arti lain yang sepadan, yaitu kata yang berarti "memalingkan pemikiran seseorang pada faham tertentu". Kata "Syi'ah" terdaat pada suku kata "syaya'a" yang berart penolong, pendukung, dan kelompok. Kata "Syi'ah" berarti orang yang mendapat dukungan orang lain. Untuk itu, syi'ah dapat digolongkan kepada umat Islam yang membela Ali dan keturunannya, yang mencintai Ali yang berhak atas kekhalifahan, bukan Abu Bakar, Umar apalagi Utsman setelah Rasulullah Saw wafat, karena Al dan keturunannya sebagai pewaris kekhalifahan beliau sampai hari kiamat. Mereka berpendapat bahwa khalifah itu sebenarnya hak Ali sebagai penerima wasiat langsung dari Rasulullah Saw untuk menggantikan kepemimpinan beliau. Nabi mewariskan ilmu lahir kepada semua sahabatnya, dan ilmu batin hanya kepada Al r.a. Selanjutnya Ali membisikkan ilmu batin itu kepada imam berikutnya, begitu juga seorang imam kepada penerusnya, demikian seterusnya Ada yang mengatakan bahwa sebutan syi'ah itu muncul pada tahun $37 \mathrm{H}$, namun ada pula yang mengatakan sejak Mu'awiyah memegang tampuk kekuasaan. Sedangkan menurut Dr. Thaha Husein bahwa para ulama fikih dan ahli sejarah memastikan pada masa Ali, kelompok Islam belum ada, dan baru muncul tidak lama sesudah ia meninggal dunia. Dengan demikian, syi'ah yang ada pada masa Ali adalah syi'ah dalam pengertian bahasa seperti yang digunakan dalam al-Qur'an. Baca: Abdul Mun'im Al-Nimr, Syi'ah Imam Mahdi...,hlm. 36-37, dan Ali As-Salus, 'Aqidah al-Imam Inda alSyi'ah alItsna 'Asyariyyah, terjemahan Asmuni Salehan Zamakhsyari, edisi 1, (Jakarta: Gema Insani Press, 1997), hlm. 31, serta Muh. Zuhri, Hukum Islam Dalam Lintasan Sejarah, edisi 1, (Jakarta: PT. Raja Grafindo Persada, 1996), hlm. 58, Ihsan Ilah Zhahier, Asy-Syi'ah wa al-Tasyayyu', terjemahan Hafied Salim, edisi 1, (Bandung: PT. Al-Ma'arif, 1984), hlm. 16, dan 19-20.
Muh. Said HM., Doktrin Syi'ah dalam Masalah Imamah dan Fikihnya

Menurut Jalaluddin Rahmat, ${ }^{7}$ bahwa khususnya golongan kaum Syi'ah sebagai kecenderungan suatu kaum, sebenarnya sudah ada sejak Rasululah Saw, merujuk kepada salah satu hadits riwayat Asakir yang berbunyi "Hai Ali, engkau dan Syi'ah-mu akan memperoleh kemenangan". Sejak zaman Rasulullah, misalnya Salman, Abu Zar, Miqdad dan Ammar serta teman-teman lainnya adalah Syi'ah Ali. Eksistensi kaum Syi'ah ini menjadi tampak jelas keberadaannya setelah Rasulullah Saw wafat. Pada suatu hari yang disebut Yaum al-Saqiifah, ketika keluarga Rasulullah sibuk mengurus jenazah Rasul, beberapa shahabat berkumpul dan menunjuk Abu Bakar sebagai khalifah. Ali dan kawankawannya baru menyadari hal ini seusai pemakaman Rasulullah. Ali menyampaikan protes, tetapi ia mendapat respon bahwa demi pertimbangan keamanan umat memerlukan tindakan segera. Ketika menjawab protes Ibn Abbas itu, Umar berkata "demi Allah, saya tahu bahwa sebenarnya Ali adalah yang paling pantas dan punya kompetensi dari semua orang untuk menjadi khalifah, tetapi karena tiga alasan, kami singkirkan Ali, pertama, ia terlalu muda, kedua, ia terikat dengan keturunan Abdul Muthalib, dan ketiga, orang tidak ingin kenabian dan kekhalifahan berhimpun dalam suatu keluarga. ${ }^{8}$ Kerena protes inilah, maka akhirnya pengikut-pengikut setia Ali memisahkan diri dan membentuk kelompok minoritas yang dikenal sebagai "Syi'ah Ali", yang hingga hari ini masih senantiasa hangat dibahas dan diperbincangkan oleh kalangan para akademisi.

Dalam perkembangannya, kaum Syi'ah terpecah ke dalam beberapa golongan, tiga yang terbesar ialah Syi'ab dua belas (Syi'ah Imamiyah atau Syi'ah Ja'fariyah) yang mayoritas, dan Syi'ah Ismailiyah (Syi'ah tujuh), serta Syi'ah Zaidiyah “. Disamping itu, ada juga beberapa sekte-sekte kecil seperti Syi’ah Saba'iyah, al-Ghurabiyah, Kisaniyah, alRafidhah dan lain sebagainya.

Dalam tulisan berikut ini, kesyi'ahan yang ingin dipahami ialah Syi'ah dua belas (atau Syi'ah Imamiyah Itsna 'Asyariyyah) kaitannya 250

${ }^{7}$ Jalaluddin Rahmat, Islam Al-Ternatif, edisi 1, (Bandung: Mizan, 1986), hlm.

${ }^{8}$ Abdul Mun'im al-Nimr, Syi'ab Imam Mabdi..., hlm. 44 
Al-Fikra: Jurnal Ilmiah Keislaman, Vol. 8, No. 2, Juli-Desember 2009

dengan doktrin keimamahan dan fikihnya, merupakan kelompok mayoritas Syi'ah yang mempercayai bahwa setelah Rasulullah wafat, umat Islam dipimpin oleh 12 imam, yaitu mazhab dalam Islam yang berpegang teguh kepada Ali Ibn Abi Thalib serta 11 imam lainnya, setelah itu ; menjadikan tauhid nubuwwah, 'adl dan imamah sebagai tonggak keimanannya, dan shalat, zakat, shaum, hajji dan khums sebagai tonggak keislamannya.

\section{Substansi Imamah dan Khalifah}

Kata imamah menurut bahasa berarti "kepemimpinan". Imam artinya "pemimpin", seperti "ketua" atau yang lainnya, baik dia memberikan petunjuk ataupun menyesatkan. Imam juga disebut khalifah, yang berarti al-Sulthan al-A'zham yaitu kekuatan (penguasa dan pemimpin tertinggi rakyat), pengganti kepemimpinan Rasul". Kata imam juga bisa digunakan untuk al-Qur'an, karena al-Qur'an itu adalah imam (pedoman) bagi umat Islam. Demikian pula, bisa digunakan untuk Rasulullah Saw karena beliau adalah pemimpin para pemimpin, yang sunnahnya diikuti oleh seluruh pemimpin. Kata imam juga digunakan untuk orang yang mengatur kemashlahatan sesuatu, untuk pemimpin pasukan, dan untuk orang dengan fungsi lainnya.

Berdasarkan makna tersebut, oleh Ali As-Salus, ${ }^{10}$ berkesimpulan bahwa kata imam berarti "pemegang kekuasaan atas umat Islam". Sementara menurut Muhammad Abu Zahrah, bahwa imamah itu juga disebut khalifah. Sebab orang yang menjadi khalifah adalah penguasa tertinggi bagi umat Islam yang menggantikan Nabi Saw. Demikian halnya khalifah itu juga disebut imam, sebab para khalifah adalah

9 Abu Bakar Aceh, Perbandingan Maz̧hab,Syi'ah,Rasionalisme Dalam Islam, (Semarang: Ramadhni, 1980), hlm. 10, dan Harun Nasution, Islam Ditinjau ..., hlm. 100

10 Pahami beberapa pengertian dimaksud menurut Ali As-Salus, 'Akidah alImamah..., hlm. 16, dan bandingkan menurut Ali Abd al-Raziq, Al-Islam wa Ushul alHukmi, edisi 3, (Mesir: Syirkah Syahimah Hadharah, 1925), hlm. 2
Muh. Said HM., Doktrin Syi'ah dalam Masalah Imamah dan Fikihnya pemimpin (imam) yang wajib ditaati. Manusia berjalan dibelakangnya sebagaimana manusia shalat di belakang imam. ${ }^{11}$

Manurut Abu Hasan al-Mawardi, seperti dikutif Hasbi AshShiddieqy, ${ }^{12}$ bahwa imamah itu ialah "suatu kedudukan yang diadakan untuk mengganti ke-Nabi-an dalam urusan memelihara agama dan mengendalikan dunia". Oleh Hasbi Ash-Shiddieqy atas dasar definisi tersebut menunjukkan bahwa Al-Mawardi sesungguhnya memasukkan siyasah dunia kedalam tugas-tugas kenabian. Oleh karena itu, wajiblah Rasul diganti untuk meneruskan tugasnya dalam urusan tersebut. Juga memberikan pengertian bahwa tugas kepala Negara, ialah memelihara dan melindungi agama, bahkan meluaskan dan mengembangkannya. Masuk kedalam pemeliharaan ini, keharusan kepala Negara membuktikan dengan amal perbuatannya, bahwa dia adalah pemelihara agama lagi memperhatikan urusan-urusannya". Demikian halnya imam dalam pengertian syara' seperti dikutif Sudirman M.Johan adalah "sebutan bagi seorang yang mempunyai kekuasaan politik dan otoritas agama untuk mengatur serta menata kepentingan dan kemashlahatan umat". Mengandung makna adanya unsur kekuasaan imam dalam bidang pemerintahan dan unsur kepemimpinan spiritual keagamaan. Dalam pemerintahan, imam berarti pemegang otoritas politik tertinggi, yang dapat mengatur birokrasi serta melaksanakan adminstrasi Negara. Sebagai pemimpin agama, imam berkewajiban menuntun serta membimbing umat untuk memahami dan melaksanakan ajaran syari'at sesuai dengan ketentuan wahyu Ilahi dan sunnah Rasul"'13.

Sedangkan imamah menurut pengertian dan keyakinan kaum Syi'ah, adalah "pemimpin umat yang meneruskan tugas Rasul, sehingga umat manusia berada dalam keselamatan dan terhindar dari kejahatan. Allah memberi otoritas kepada imam untuk membimbing

11 Al-Syahrastani, Al-Milal wa Al-Nihal, Jilid I, Cairo: Musthafa al-Bab alHalabi, 1967), hlm. 24

12 T.M.Hasbi Ash-Shiddieqy, Ilmu Kenegaraan Dalam Fiqib Islam. Edisi1, (Jakarta: Bulan Bitang, 1971), hlm. 43-44

3 Sudirman M.Johan, Politik Keagamaan Dalam Islam, edisi 1, (Pekanbaru: Susqa Press, 1995), hlm. 62 
Al-Fikra: Jurnal Ilmiah Keislaman, Vol. 8, No. 2, Juli-Desember 2009

dan memimpin umat manusia, dan dapat menerima manfaat atas kepemimpinan imam, terutama dalam keadilan, persamaan dan ketenteraman dalam menjalankan ketentuan dan peraturan-peraturan ilahiah". Selain itu, kaum Syi'ah juga memandang bahwa imam itu sebagai rukun agama yang harus diyakini oleh semua orang Syi'ah yang ditetapkan berdasarkan nash dan wasiat. Dengan demikian, Syi'ah mendapat pelimpahan kekuasaan dari Allah melalui Nabi dengan wasiat. Oleh karena itu, imam harus ditaati dan dipatuhi. Sebab imam adalah pribadi yang makshum tidak mungkin berbuat salah dan berbuat dosa. Kaum Syi'ah-pun memandang fungsi dan kedudukan imam sama dengan fungsi dan kedudukan nabi dalam hal menerima risalah dari Tuhan. Sedangkan yang membedakannya adalah bahwa nabi menerima wahyu dari Allah, sedangkan imam tidak menerima wahyu dari Allah"14. Dalam versi lain menurut kaum Syi'ah bahwa imam adalah pribadi yang sempurna, sama halnya dengan pribadi para nabi dan rasul. Oleh karena itu, kepemimpinan imam sama dengan kepemimpinan para nabi yang wajib ditaati oleh umat manusia. Ia dapat berlaku adil dan jujur terhadap sesama manusia, dan imam-pun mempunyai kemampuan dalam membuat peraturan sesuai dengan maksud syara' atau bimbingan dari Allah"15.

Menurut kesimpulan Ali As-Salus, ${ }^{16}$ bahwa prinsip keyakinan kaum Syi'ah Imamiyah mengenai persoalan imamah adalah sebagai berikut :

1. Imamah adalah salah satu rukun agama

2. Imam itu seperti Nabi dalam kemaksuman, sifat dan ilmunya

3. Pada setiap masa harus ada seorang Imam

4. Para Imam adalah ulil amri yang Allah perintahkan untuk ditaati

5. Imamah harus dengan ketentuan Allah melalui penjelasan Rasul-Nya.

14 Al-Syahrastani, Al-Milal..., hlm. 146

15 Zahrah, Tarikh..., hlm. 62

16 Ali As-Salus, Akidah al-Imamah..., hlm. 36-39
Muh. Said HM., Doktrin Syi'ah dalam Masalah Imamah dan Fikibnya

Prinsip keyakinan kaum Syi'ah tersebut, menurut analisis Sudirman M.Johan bahwa kaum Syi'ah sangat membesarkan fungsi dan peranan imam, seakan-akan tanpa kehadiran imam, risalah yang dibawa rasul tidak akan jalan risalah, akan berhenti dengan wafatnya Rasul. Kepemimpinan imam merupakan salah satu alternatif sebagai pengganti kepemimpinan Nabi, baik dalam persoalan duniawi, maupun dalam persoalan yang berhubungan dengan keagamaan"17.

Keimamahan itu menurut Ihsan Ilahi Zhahier adalah suatu hal yang wajib, sebab ia memanifestasikan kepemimpinan umum dalam urusan agama dan dunia, yang harus dipegangi oleh salah seorang, sebagai pengganti Nabi Muhammad Saw. Keimamahan itu merupakan hal yang wajib, sebab ia adalah suatu karunia, sedang karunia itu adalah suatu hal yang wajib. Keimamahan itu disebut suatu karunia, sebab apabila manusia mempunyai seorang pemimpin yang ditaati, lagi dapat membimbing, mampu mengekang orang zhalim dari perbuatan zhalimnya, mendorong manusi untuk mengerjakan kebajikan dan mengekang mereka dari kejahatan, maka manusia lebih dekat kepada kebaikan dan terjauh dari kerusakan. Itulah "karunia"18.

Kaum Syi'ah lebih lanjut mereka berpendapat bahwa jabatan kepala nagara (imam), bukanlah hak setiap orang-orang Islam, bahkan pula tidak hak setiap orang Quraisy, melainkan adalah hak monopoli Ali Ibn Abi Thalib dan keturunannya. Jadi imamah dalam teori Syi'ah mempunyai bentuk kerajaan dan turun temurun dari Bapak ke anak, seterusnya ke cucu dan demikian selanjutnya. Semestinya yang menggantikan Nabi Muhammad sebagai kepala Negara dalam faham Syi'ah, adalah anak beliau. Tetapi karena beliau tak mempunyai anak laki-laki yang hidup, jabatan itu seharusnya pergi ke anggota keluarga beliau yang terdekat. Ali Ibn Abi Thalib adalah anak paman beliau dan yang terpenting lagi adalah pula menantu beliau. Oleh karena itu, Alilah anggota keluarga Nabi yang terdekat. Dengan demikian, yang menggatikan Nabi Muhammad dengan kapasitasnya sebagai Kepala

${ }^{17}$ Sudirman M. Johan, Politik Keagamaan..., hlm. 93

18 Ihsan Ilahi Zahier, Al-Syi'ah wa Al-Tasyayyu', terjemahan Hafied Salim, edisi 1, (Bandung: PT. Al-Ma’arif, 1984), hlm. 380 
Al-Fikra: Jurnal Ilmiah Keislaman, Vol. 8, No. 2, Juli-Desember 2009

Negara seharusnya Ali dan seterusnya keturunannya ; anak-anak serta cucu-cucunya, dan bukan Abu Bakar, Umar Ibn al-Khaththab, Utsman Ibn 'Affan, Bani Umaiyyah dan Bani Abbasiyyah. Oleh sebab itu, kekhalifahan Abu Bakar, Umar dan Utsman tidak diakui oleh kebanyakan kaum Syi'ah dan demikian juga eksistensi pemerintahan Dinasti Bani Umaiyyah dan Dinasti Bani Abbasiyyah"19.

Seperti telah disingung bahwa ada 12 orang imam yang telah ditetapkan mereka sesudah Rasulullah Saw. wafat, mereka itu adalah sebagai berikut :

1. Abul Hasan, Ali Ibn Abi Thalib (lahir pada 10 tahun sebelum kenabian dan syahid pada tahun $40 \mathrm{H})$.

2. Abu Muhammad, Hasan Ibn Ali $(3-50 \mathrm{H})$

3. Abu Abdillah, Husein Ibn Ali $(4-61 \mathrm{H})$

4. Abu Muhammad, Ali Ibn Husein (Gelar Zainal Abidin, 38 - 95 $\mathrm{H})$

5. Abu Ja'far, Muhammad Ib Ali Al-Baqir $(57-114 \mathrm{H})$

6. Abu Abdillah, Ja'far Ibn Muhammad ash-Shadiq $(83-148 \mathrm{H})$

7. AbuIbrahim, Musa Ibn Ja'far al-kadzim $(128-183 \mathrm{H})$

8. Abul Hasan, Ali Ibn Musa ar-Ridha $(148-202 \mathrm{H})$

9. Abu Ja'far Muhammad Ibn Ali al-Jawad $(195-220 \mathrm{H})$

10. Abul Hasan, Ali Ibn Muhammad al-Hadi $(212-254 \mathrm{H})$

11. Abu Muhammad, Hasan Ibn Ali al-Askari $(232-260 \mathrm{H})$

12. Abul Qasim, Muhammad Ibn Hasan al-Mahdi (Imam yang ghaib dan dinantikan kedatangannya untuk menegakkan keadilan di muka bumi setelah dipenuhi oleh kezhaliman. Dikatakan bahwa al-Mahd lahir pada tahun $256 \mathrm{H}$, mengalami masa ghaib kecil pada tahun $260 \mathrm{H}$, dan masa ghaib besar pada tahun $329 \mathrm{H}$. Ia hidup sampai hari kiamat sehingga bumi tidak sunyi dari imam. Imam tersebut menghilang buat sementara dan akan kembali lagi sebagai al-Mahdi untuk langsung memimpin umat. Oleh karena itu, ia disebut imam bersembunyi (al-Mustatir), atau imam dinanti (al-Muntzhir).

${ }^{19}$ Harun Nasution, IslamDitinjau ..., hlm. 97-98
Muh. Said HM., Doktrin Syi'ah dalam Masalah Imamah dan Fikibnya

Selama bersembunyi ia memimpin umat melalui Raja-raja yang memegang kekuasaan dan ulama-ulama mujtahid Syi'ah"20.

Menunjukkan bahwa dalam doktrin kaum syi'ah memandang imam dapat saja mastur (tersembunyi). Meskipun imam berada dalam keadaan mastur, imam-imam yang mastur sebagaimana halnya imam yang zahir, tetap wajib ditaati. Dengan demikian seorang imam (faqih) yang melaksanakan perintah imam yang mastur harus di ikuti. Sebab ia dipandang sebagai penerima perintah dan pelaksana dari imam yang mastur, baik yang berhubungan dengan masalah politik maupun persoalan agama. ${ }^{21}$

\section{Sumber Keharusan Adanya Imamah}

Sebenarnya kaum Syi'ah dengan golongan-golongan lainnya (ahlu al-Sunnah kebanyakan, Khawarij dan Mu'tazilah) sependapat tentang wajib adanya pemerintahan (imamah). Hanya saja kaum Syi'ah mempunyai paham yang tersendiri dalam memaknakan keharusan adanya pemerintahan. Mereka beragumentasi "adanya pemerintahan adalah suatu tugas Allah, bukan tugasnya ummat"22. Imamah sebagai dasar agama yang ditetapkan melalui nash dan wasiat, bukan atas dasar pertimbangan akal dan ijma'. Sebab imam mengemban dan meneruskan tugas rasul untuk menyebarluaskan ajaran syari'at, sehingga umat manusia berada dalam persamaan dan ketenteraman dalam melaksanakan doktrin syari'at. Dengan demikian mengangkat imam merupakan suatu kewajiban bagi Allah, karena Allah tidak terlibat langsung menangani dan melaksanakan hukum-hukum syari'at Islam.

Persoalan imamah bukan sekedar persoalan siapa yang akan menjadi pemimpin politik umat, akan tetapi, persoalannya mencakup

20 Ali As-Salus, Akidah al-Imamah..., hlm. 35-40, dan Harun Nasution, Islam Ditinjau..., hlm. 99, Kedua belas nama-nama imam tersebut bandingkan menurut M.Ali Hasan, Perbandingan Marhab, edisi 1, (Jakarta: PT. Raja Grafindo Persada, 1995), hlm. 251. Mengenai masalah Imam Tersembunyi dimaksud, baca: Ahmad Amin, Dhuha Al-Islam, (Cairo: Maktabah al-Nahdhah, 1964), hlm. 226

${ }^{21}$ Sudirman M. Johan, Politik Keagamaan..., hlm. 137

${ }_{22}$ T.M. Hasbi Ash-Shidieqy, Ilmu Kenegaraan..., hlm. 61 
Al-Fikra: Jurnal Ilmiah Keislaman, Vol. 8, No. 2, Juli-Desember 2009

soal syari'at yang telah dibawa oleh rasul dan imam berfungsi sebagai penerus risalah rasul. Hal ini berarti bahwa imam bukan hanya pemimpin politik, tetapi juga pemimpin agama. Argumentasi Syi'ah di atas didasarkan dengan nash al-Qur'an dalam surat al-Ahzab ayat 72, yang intinya bahwa "Allah memberikan amanah kepada makbluknya selain manusia, rupanya mereka tidak sanggup, lalu Allab mengamanabkan kepada manusia dan manusia menerimanya". Bagi kaum Syi'ah menurut analisis Sudirman M.Johan bahwa penerimaan manusia terhadap amanah itu ditafsirkan sebagai misi esotorik pada imam dan wali-wali Allah"23.

Selanjutnya kaum Syi'ah dalam pandangannya bahwa ketentuan nash al-Qur'an dan Sunnah tentang dasar hukum imamah merupakan berkah Allah kepada hamba-Nya. Alasannya ialah bahwa semua bentuk yang dapat membawa manusia tunduk dan patuh kepada penciptaannya dan terhindar dari semua macam yang dapat mengakibatkan perbuatan dosa, adalah rahmat Allah kepada hambaNya. Agar Rahmat Allah itu tetap pada manusia, Allah mengangkat seorang imam sebagai tanda rahmat-Nya kepada umat manusia. Hal tersebut sesuai dengan yang mereka pahami dari Al-Qur'an, surat AlAmbiya' ayat 73, yang artinya : Kami telab menjadikan mereka itu sebagai pemimpi-pemimpin yang memberi petunjuk dengan perintah Kami dan telah Kami wabyukan kepada mereka mengerjakan kebaikan”.

Selain atas dasar nash dan wasiat wajibnya masalah imamah ini, dikalangan kaum Syi'ah juga punya argumentasi lain, dengan alasan antara lain sebagai berikut :

1. Kita berhajat kepada kepala Negara supaya terus menerus ada orang yang mendorong kita kepada menunaikan kewajibankewajiban yang ditetapkan oleh agama dan menjauhkan keburukan-keburukan yang ditetapkan akal. Supaya ada pula orang yang memelihara agama.

2. Tak ada jalan untuk mengenal Allah, melainkan dengan ajakan Rasul dan kepala Negara. Maka karenanya wajib-lah Allah mengisi dunia ini dengan orang yang terpelihara dari kesalahan
Muh. Said HM., Doktrin Syi'ah dalam Masalah Imamah dan Fikibnya

3. Bahwasanya menusia memerlukan seseorang imam untuk menerangkan kepada mereka, sehingga mereka mengetahui untuk memelihara mereka dari hal-hal yang menakutkan dan bencana.

4. Menetapkan imamah dengan pilihan manusia sendiri, bukan dengan Allah yang menentukan, menimbulkan kekacauan. Untuk menghilangkan kekacauan ini, hendaklah orang yang diangkat sebagai kepala Negara dinashkan oleh Allah sendiri.

5. Kepala Negara haruslah terpelihara dari maksiat, haruslah orang yang paling utama, haruslah orang yang paling pandai. Maka yang dapat mengetahui orang yang demikian itu, hanyalah Allah sendiri. Karena itu tidak dapat kita mengangkat seseorang menjadi imam, tanpa dinashkan oleh Allah sendiri.

6. Kalau kepala Negara yang berkuasa itu, berbuat salah, berarti dia tidak makshum. Maka jika kita mengikuti orang-orang yang demikian, berartilah kita mengikuti dosa dan maksiat. Menyuruh kita mengikuti dosa dan maksiat, tidak boleh bagi Allah. Kalau kita tidak mengikutinya, bukanlah dia kepala negara, padahal kepala Negara orang yang harus kita ikuti.

7. Orang yang memilih imam dengan jalan bai'at, tidak dapat bertindak dengan sendirinya terhadap urusan umat Islam. Maka bagaimana mereka mempunyai kesanggupan untuk memberikan kekuasaan kepada orang lain terhadap isi dunia ini ?

8. Kepala Negara adalah naib (wakil) Allah dan Rasul-Nya. Wakil seseorang adalah orang yang disukai oleh orang yang diwakilinya. Maka karena itu, kepala Negara harus yang dinashkan oleh Allah dan Rasul-Nya.

9. Kepala Negara adalah hujjah Allah atas makhluk-Nya, atau hujjah Allah dimuka bumi ini, yakni keterangan-Nya yang menerangkan bahwa Allah bermaksud menyampaikan agamaNya kepada hamba-hamba-Nya dan memberatkan mereka menjalankan perintah dan menjauhi larangan. Maka kalau

${ }^{23}$ Sudirman M. Johan, Politik Keagamaan..., hlm. 115 
A1-Fikra: Jurnal Ilmiah Keislaman, Vol. 8, No. 2, Juli-Desember 2009

bukan karena dalil ini, tentulah manusia boeh berbuat sekehendaknya. ${ }^{24}$

Secara sederhana dapat disimpulkan bahwa kaum Syi'ah memandang persoalan imamah adalah wajib menurut agama, baik pada akal maupun pada syara', sebagaimana persoalan kenabian itu wajib menurut fithrah, baik pada akal maupun pada syara'. Keperluan manusia kepada kepala Negara yang wajib ditaati, yang memelihara hukum-hukum syara', sama dengan kebutuhan manusia kepada Nabi, dan kebutuhan manusia kepada tetap berlakunya hukum-hukum syara'. Sama dengan kebutuhan mereka kepada adanya syara' sendiri.

\section{Pengangkatan Imam dan Tugas Utamanya}

Dapat dipastikan bahwa seluruh ahli ijtihad dari golongan Islam selain dari pada golongan Syi'ah yang "aneh" ini, menetapkan bahwa jalan mengangkat kepala Negara, ialah dengan melalui proses pemilihan dan persesuaian pendapat dalam suatu lembaga (abl al-halli wa al-'Aqd = abl al-Ikbtiyar ; abl al-Ijtibad, mereka adalah orang-orang yang diserahkan tugas kepadanya mengurus memilih kepala Negara, yang melakukan aqad, dan sekaligus bertanggung jawab dalam hal tersebut), bukan ditentukan atas dasar nash, atau bukan ditentukan oleh Allah dan Rasul-Nya. ${ }^{25}$ Lain halnya dengan golongan Syi'ah, tidak mengenal adanya suatu lembaga yang resmi, seperti abl al-billi wa al'aqd, sebab menurut mereka bahwa persoalan imamah bukan wewenang manusia. Berarti juga bahwa tidak adanya suatu lembaga yang dapat mewakili kehendak dan kemauan umat. Jika ada, tidak ada artinya. Semuanya itu berasal dari Tuhan. Tuhan pula yang menentukan imam sebagai pemimpin umat. Menurut Sudirman M.Johan bahwa penunjukan dan pengangkatan seorang imam oleh Tuhan itu dalam konsepsi Syi'ah adalah suatu hal yang logis. Sebab Tuhan mengetahui pribadi muslim yang mampu melaksanakan amanah-Nya. Proses penunjukan itu adalah melalui wasiat dari Nabi Muhammad Saw. kepada Ali Ibn Abi Thalib sebagai penerima wasi

${ }^{24}$ T.M. Hasbi Ash-Shidieqy, Imu Kenegaraan..., hlm. 62-63

25 Ibid, hlm. 64-66
Muh. Said HM., Doktrin Syi'ah dalam Masalah Imamah dan Fikihnya

pertama, dan berikutnya kepada imam-imam yang mempunyai hubungan darah dengan imam Ali Ibn Abi Thalib"26.

Sebaliknya, menurut Ihsan Ilahi Zhahier bahwa sebenarnya kaum Syi'ah tidak pernah dapat menetapkan keimamahan para imam mereka, sekalipun mereka berdalih dengan adanya nash dan penunjukan bahwasanya seseorang tidak dapat menjadi imam kecuali bila untuknya dibuatkan nash penetapan oleh pihak imam yang sebelumnya, dengan menunjuk bahwa ialah orang yang dinashkan menjadi imam. Yang lebih mengherankan lagi bahwa imam-imam itu sendiri dari pihaknya tidak menetapkan keimaman mereka menurut apa yang diceritakan oleh kaum Syi'ah, dan tidak pula menurut syaratsyarat yang mereka sebutkan, seperti misalnya ; keharusan adanya wasiat, dicapainya usia dewasa, cocoknya baju besi Rasulullah dengan badan imam yang bersangkutan, keberadaan senjata Rasulullah di tangannya, dimandikannya imam yang wafat oleh seorang putra yang akan menggantikannya sebagai imam, dan babwa mereka orang-orang yang paling alim, berpengetabuan dan paling berani, serta memiliki pengetahuan tentang hal-hal yang ghaib dan sifat-sifat lain yang mereka jadikan pertanda dan syarat bagi keimaman seseorang. Bahkan sebaliknya, untuk membuktikan keimamannya, mereka malahan menggunakan tipuan praktek-praktek dukun dan bermacam-macam jenis sihir yang sesuai dengan dakwah kaum Syi'ah. Seandainya benar para imam itu masing-masing dibekali dengan sebuah wasiat (dari imam sebelumnya, yang didukung oleh sebuah nash penetapan menjadi imam) dan ditunjang dengan penunjukan (dari imam sebelumnya), maka sudah barang tentu mereka tidak perlu menggunakan tipuan, sihir dan sebagainya itu. Sebagai salah satu contoh historisnya, adalah dengan cerita di bawah berikut :

"Ketika Husain Ibn Ali terbunuh, Muhammad Ibn Hanafiah mengundang Ali Ibn Husain, dan berkata kepadanya : Ayahmu telah meninggal tanpa meninggalkan wasiat. Aku adalah pamanmu dan saudara ayahmu, dari segi usiaku kiranya aku lebih berhak atas keimaman daripada-mu, mengingat usiamu masih muda. Maka janganlah engkau membantahku mengenai perkara

${ }^{26}$ Sudirman M. Johan, Politik Keagamaan..., hlm. 99-100 
Al-Fikra: Jurnal Ilmiah Keislaman, Vol. 8, No. 2, Juli-Desember 2009

itu. Ali Ibn Husain menjawab "marilah kita datang ke Hajar Aswad dan mengajukan perkara ini demi suatu keputusan.”. Majulah lebih dahulu memohon kepada Allah, supaya Hajar Aswad berbicara dengan anda sesuai apa yang anda kehendaki. Namun Hajar Aswad tidak menjawab apa-apa. Lalu tiba giliran Husain Ibn Ali memanjatkan doa kepada Allah, tiba-tiba Hajar Aswad berbicara dengan bahasa arab yang jelas dengan kalimat

"allahumma, sesungguhnya wasiat dan keimaman jatuh kepada Ali Ibn Husain"27.

Kisah tersebut menunjukkan bahwa para imam itu telah bertentangan dengan dasar dan asas yang ditetapkan oleh kaum Syi'ah sendiri, bahwasanya keimaman itu hanya ditetapkan dengan adanya suatu nash dan penunjukan, sehingga tiada seorang imam-pun, melainkan ia harus ditetapkan dengan nash dan ditunjuk oleh imam yang sebelumnya, sebab menurut pernyataan kaum Syi'ah sendiri, Imam-imam mereka tidak mungkin berselisih dan tidak bertikai satu sama lain, namun kabalikannyalah yang justeru terjadi dalam kenyataan, hal mana disebabkan oleh ketiadaan nash, dan ketiadaan penunjukan, serta tidak dikenalnya kesemuanya itu, sekalipun di antara putra-putra dari satu ayah. Seandainya nash, wasiat dan penunjukan itu sudah terjadi secara biasa, maka sudah barang tentu mereka tidak terpaksa melakukan bermacam-macam ketakhayulan untuk memantapkan keimaman mereka.

Sementara menurut penelitian Sudirman M.Johan, ${ }^{28}$ bahwa fakta historis tentang institusi imamah, ternyata Syi'ah-pun mengutamakan bai'at umat untuk mendapatkan legitimasi hukum. Jika kaum Syi'ah meyakini sepenuhnya penunjukan Tuhan terhadap imam, tentu mereka tidak memerlukan pengakuan yang bersifat pembai'atan dari umat. Sebab otoritas Ilahi lebih utama daipada otoritas manusia. Selain itu fakta-pun menunjukkan bahwa para imam Syi'ah itu baru dapat melaksanakan otoritas politiknya setelah mendapat pembai'atan dari umat. Sedangkan sebelumnya ia tidak mempunyai wewenang dan

${ }^{27}$ Ihsan Ilahi Zhahier, Al-Syi'ab wa ..., hlm. 370-372

${ }^{28}$ Sudirman M. Johan, Politik Keagamaan..., hlm. 105
Muh. Said HM., Doktrin Syi'ah dalam Masalab Imamah dan Fikihnya

kekuasaan politik untuk memimpin umat. Hal ini dapat dilihat pada imam Ali. Sebelum ia mendapat bai'at dari rakyat, dia tidak mempunyai kekuasaan politik. Kekuasaan politik diperolehnya setelah adanya pembai'atan terhadap dirinya. Sejak itulah secara resmi ia menjadi pemimpin umat menggantikan khalifah Utsman Ibn Affan. Hal yang sama juga berlaku bagi imam-imam Syi'ah yang lain”.

Selanjutnya sebagaimana dipahami bahwa masalah imamah adalah suatu wilayah yang lengkap dalam segala pekerjaan dan persoalan. Baik pekerjaan itu berpautan dengan urusan agama, ataupun berpautan dengan keduniaan. Urusan-urusan itu semua tak mungkin dapat dikerjakan sendiri oleh seorang kepala Negara. Dia sangat perlu kepada adanya perwakilan-perwakilan, perlu adanya pembantu-pembantu, pegawai-pegawai yang diserahkan kepada mereka sebagai macam tugas untuk memenuhi tugas Negara. Tugas kepala Negara yang diserahkan kepadanya menurut Al-Mawardi, yaitu "mengurusi umat, tak dapat diselesaikan sendiri semuanya tanpa wakilnya". Sementara menurut Ibnu Khaldum, bahwa "kepala Negara itu adalah seorang yang lemah, yang memikul tugas-tugas yang berat. Karena itu, perlu dibantu oleh putra-putra bangsanya. Kalau dia memerlukan bantuan dalam kebutuhan hari-hari, maka tentulah ia memerlukan bantuan dalam mengendalikan rakyatnya.$^{29}$

Dalam keyakinan kaum Syi'ah bahwa imam bukan hanya dipandang sebagai pemimpin agama, tetapi juga dipandang sebagai pemimpin politik. Sebagai pemimpin agama, imam bertugas membimbing dan membina umat untuk memahami doktrin agama dengan baik dan benar. Sehingga umat dapat menjalankan ajaran syari'at sesuai dengan prinsip al-Qur'an dan al-Sunnah. Sedangkan sebagai pemimpin politik, imam bertugas memelihara dan meningkatkan kesejahteraan, keadilan, serta ketertiban umat, sehingga umat dapat menjalankan syariat Islam dengan aman dan tenteram. Adapun wewenang dan kekuasan imam, baik dibidang politik dan agama, berasal dari Tuhan dan bukan dari umat atau lembaga ahl al-hill wa al'aqd. Imam yang menerima otoritas Ilahi adalah orang yang memiliki

${ }_{29}^{29}$ T.M. Hasbi Ash-Shiddieqy, Ilmu Kenegaraan, hlm. 79 
Al-Fikra: Jurnal Ilmiah Keislaman, Vol. 8, No. 2, Juli-Desember 2009

sifat 'ishmah dan ma'shum, ${ }^{30}$ sehingga mempunyai kemampuan untuk memimpin umat, baik dalam urusan duniawi maupun dalam urusan keagamaan, karena senantiasa mendapat bimbingan serta petunjuk dari Allah. Imam mampu menafsirkan hukum-hukum syara' dalam menata berbagai persoalan yang timbul dalam masyarakat. Kemampuan seperti itu tidak dimiliki orang lain, karena mereka tidak mempunya sifat 'ishmah dan ma'shum, di samping tidak mempunyai ilmu Ilahiyah. Hal demikian menurut Muhammad Ridha al-Muzhafir, menunjukkan keutamaan kepemimpinan imam dalam konsepsi kaum Syi'ah, yang memiliki nilai-niai kebenaran dalam melaksanakan tugastugas dan menegakkan syari'at"31.

\section{Kemuliaan Imam dan Pertanggungjawaban Tugasnya}

Pada umumnya kaum Syi'ah tetap sepakat tentang al-Imamah dan imamah hanya ada pada Imam Ali dan keturunannya sampai hari kiamat. Mereka menjadi pemimpin dunia dan akhirat, artinya merekalah yang menjadi pemimpin umat Islam di dunia ini. Mereka juga sepakat, bahwa para imam tersebut ma'shum dari kekeliruan dan kesalahan, sebagaimana para nabi, ucapan para imam sama dengan ucapan orang-orang ma'shum yang tidak boleh dikomentari. Jadi Imam ma'shum menurut mereka adalah pemimpin umat manusia dunia, ucapan, perintah dan larangannya yang berkaitan dengan dunia terlepas dari kesalahan dan kekeliruan, dan umat manusia wajib mentaatinya, tidak boleh meragukan. Ia sosok manusia ma'shum dan sempurna segalanya, derajatnya di atas manusia biasa dan di bawah derajat nabi sedikit". Bila dia ridha terhadap seseorang berarti pertanda orang tersebut mendapat ridha Allah, sekaligus alamat akan masuk surga. Tapi kalau dia murka, maka murkanya berarti tanda murka Allah, yang berarti alamat akan masuk neraka. Maka tempat kembalinya seorang muslim tergantung ridha imam atau murkanya,

30 Al-Syahrastani, Al-Milal..., hlm. 146

${ }^{31}$ Sudirman M. Johan, Politik Keagamaan..., hlm. 129
Muh. Said HM., Doktrin Syi'ah dalam Masalah Imamah dan Fikibnya

karena mereka adalah para wakil yang mempunyai kedudukan sama dengan yang diwakilinya"32.

Menurut Abdul Mun'im al-Nimr lebih lanjut bahwa Ahmad Amin telah menulis tentang sifat-sifat yang dimiliki oleh para imam, dinukil dari kitab "al-kafiy" karya Ja'far Muhammad Ibn Ya'qub alKhulainiy, salah satu kitab fikih rujukan dikalangan kaum Syi'ah dua belas (Syi'ah Itsna 'Asyariyah), katanya sebagai berikut:

1. Syi'ah yakin bahwa imam mendapat wahyu, sekalipun caranya berbeda dengan Nabi dan Rasul, orang yang tidak memiliki imam tersesat. Barang siapa meninggal tanpa mempunyai imam, maka dia mati kafir dan munafik.

2. Para imam adalah cahaya Allah, sebagaimana dalam Firman Allah, "...Maka berimanlah kamu kepada Allah dan Rasul-Nya serta cahaya yang kami turunkan ..” yang dimaksud al-nur (cahaya) di sini menurut mereka bukan al-Qur'an, melainkan para imam.

3. Para imam adalah tiang bumi yang dikuatkan oleh penduduknya.

4. Imam suci dari dosa, bersih dari cacat dan mendapat ilmu khusus.

5. Amaliah manusia akan diperlihatkan kepada Nabi dan para Imam.

6. Para imam adalah pemangku risalah, malaikat dan rahasia Allah di muka Bumi, juga sebagai wakil Allah untuk para hamba-Nya.

7. Para imam mempunyai kitab-kitab yang diturunkan Allah kepada Rasul, mereka mengetahui semua bahasanya.

8. Hanya para imam yang mengetahui al-Qur'an dan ilmunya, diperoleh secara turun temurun dari Imam Ali

9. Mereka mengetahui ilmu masa lalu, sekarang dan yang akan dating, tidak ada sesuatupun yang tidak mereka ketahui, Allah tidak pernah mengajarkan suatu ilmupun kepada NabiSaw, melainkan Dia memerintahkan kepada beliau untuk mengajarkan kepada Imam Ali, kemudian ilmu tersebut diajarkan kepada para imam sesudahnya.

32 Abdul Mun'im al-Nimr, Syi'ah Imam Mabdi..., hlm. 58 
Al-Fikra: Jurnal Ilmiah Keislaman, Vol. 8, No. 2, Juli-Desember 2009

10. Rasulullah Saw selalu didampingi oleh ruh yang agung, baik Jibril atau Mikail, demikian juga para imam.

11. Para malaikat memasuki rumah para imam, lalu menginjak karpet mereka dengan membawa berita.

12. Semua bumi ini milik imam, ahl al-bait karena merekalah yang mewarisi bumi ini sebagaimana yang disebutkan dalam ayat "..bahwa bumi ini diwarisi oleh para hamba-Ku yang shaleh.." yang dimaksud para hamba menurut mereka adalah para imam itu sendiri" 33 .

Senada dengan hal tersebut menurut Al-Syahrastani, ${ }^{34}$ bahwa sesungguhnya kaum Syi'ah, memandang imam adalah "segalanya" sebagai manusia dengan kepribadian yang paripurna, terlepas dari dosa-dosa dan kesalahan, dan semua yang berasal dari imam itu sendiri adalah segalanya baik. Oleh karena itu dalam soal pertanggungjawabannya sebagai imam, tidak ada peluang bagi orang lain untuk meminta pertanggungjawabannya dalam melaksanakan tugas-tugasnya sebagai pemimpin agama dan politik.

Seorang imam, sebagaimana dipahami. tidak diangkat atau ditetapkan oleh umat dalam suatu lembaga, melainkan ia menerima Rahmat dari Allah. Sebagai manusia yang menerima Rahmat, maka ia hanya bertanggung jawab kepada Allah, tidak bertanggungjawab kepada umat. Oleh karena itu, apapun yang dibuat oleh imam dalam persoalan dunia dan agama adalah senantiasa dibawa control Allah, dalam hubungan tersebut, umat tidak punya peranan sama sekal dalam mengangkat atau menetapkan imam, apa lagi mengontrol pemerintahan imam". Jika imam bertanggungjawab kepada manusia, berarti imam bukanlah berdasarkan wasiat dan ini bertentangan dengan ketentuan nash. Sebab dalam faham Syi'ah, imam itu didasarkan atas ketentuan nash dan wasiat. Dengan demikian, pertanggungjawaban seorang imam itu dikembalikan kepada Allah. Pertanggungjawaban imam kepada Allah bukanlah realitas duniawi, tetapi di akhirat kelak. Semasa hidup di dunia ini, imam bebas

33 Ibid, hlm. 59-60

34 Al-Syahrastani, Al-Milal..., hlm. 146
Muh. Said HM., Dok.trin Syi'ah dalam Masalah Imamah dan Fikihnya

melaksanakan kebijaksanaannya, meskipun kebijaksnaan itu bertentangan dengan kehendak dan kemauan umat.

Akhirnya implikasi dari pandangan kaum Syi'ah terhadap kema'shuman diri imam itu dengan segala keistimewaannya adalah tidak mengenal adanya pemecatan imam selama dalam pangkuan jabatannya. Dengan kata lain, kaum Syi'ah pun tidak mengenal adanya suksesi selama imam masih hidup. Menunjukan indikasi bahwa untuk dapat berlangsungnya suksesi keimamahan dalam doktrin kaum Syi'ah adalah begitu wafatnya seorang imam"35.

\section{Prinsip dan Corak Fikihnya}

Banyak orang menyangka bahwa kaum syi'ah dalam menetapkan hukum-hukum fikih dari sumber yang berlainan dengan kaum sunni, anggapan ini adalah salah menurut M. Ali Hasan. ${ }^{36}$ Menurutnya bahwa baik kaum Sunni dan Syi'ah menganggap sumber hukum yang utama adalah al-Qur'an dan al-Sunnah. Sementara al-Ijma' dan alQiyas juga mereka gunakan, namun dengan bermacam-macam istilah. Al-Sunnah bagi kaum syi'ah adalah penyempurnaan bagi al-Qur'an, merupakan satu sumber yang tidak boleh diragukan akan kebenarannya. Ia hampir tidak berbeda dengan al-Qur'an, karena Allah mengakui bahwa Nabi tidak menuturkan sesuatu karena hawa nafsunya kecuali firman yang diwahyukan Allah kepadanya. Kaum syi'ah menganggap al-Sunnah sebagai dasar hukum kedua. Kaum Syi'ah menganggap pintu ijtihad selamanya terbuka sepanjang zaman, meletakkan posisi ijtihad lebih tinggi dari al-Ijma' dan al-Qiyas. Oleh karena itu, Imam bagi mereka berkedudukan sebagai kepala mujtahid (Sayyid al-Mujtahid), tempat mereka memperoleh pengetahuan agama.

Pada umumnya dapat dipahami, bahwa keputusan fikih mereka sebenarnya dari aspek lainnya ada kesamaannya dengan mazhab Syafi'i. Hanya beberapa hal yang berbeda. Pada memang pada mulanya ulama Syi'ah (Imamiyah) dalam melaksanakan ijtihad mengikuti metode Imam Syafi'i dalam menetapkan hukum, tetapi lama kelamaan,

${ }^{35}$ Sudriman M. Johan, Politik Keagamaan..., hlm. 147-150

${ }^{36}$ Keterangan lebih lanjut, M. Ali Hasan, Perbandingan Maŗhab, hlm. 240. 
A1-Fikra: Jurnal Ilmiah Keislaman, Vol. 8, No. 2, Juli-Desember 2009

mereka menetapkan ushul figh sendiri dan beristinbath dengan caranya sendiri pula. Mereka berijtihad menggunakan al-Maslahat, bukan dengan al-Qiyas. ${ }^{37}$ Kelihatannya, perbedaan-perbedaan yang mencolok antara kaum Syi'ah dengan non-Syi'ah bukan di bidang fikihnya, tetapi melainkan di bidang 'akidah, terutama konsep imamah. Namun demikian, Syi'ah sebagai sebuah sekte merasa perlu menggalang persatuan mereka dalam bentuk ritual dan hubungan social yang dituangkan dalam keputusan-keputusan fikih.

Di antara hukum-hukum fikih khusus bagi mazhab Syi'ah (Imamiyyah) adalah sebagai berikut :

1. Tidak boleh bersujud di atas apa yang selain tanah dan tumbuh-tumbuhan (rumput). Jadi tidak sah shalat kalau sujud di atas wol, kulit dan lain-lain misalnya menggunakan sajadah waktu sujud.

2. Istinja' dengan batu khusus pada buang air besar saja, tidak boleh digunakan untuk istinja' dari kencing.

3. Tidak sah mengusap kepala dalam wudhu' kecuali dengan sisa air yang masih melekat di tangan ketika membasuh kedua belah tangan. Jika orang berwudhu' membasahi lagi tangannya untuk mengusap kepalanya, maka wudhu'nya tidak sah, meskipun ia tela melap tangannya, ia harus mengulangi wudhu'nya.

4. Laki-laki berzina dengan seorang perempuan yang masih mempunyai suami, maka haram selama-lamanya baginya untuk menikahinya, meskipun suaminya telah menceraikannya.

5. Nikah muth'ah termasuk syari'at Islam yang berlaku hingga hari kiamat. Dasarnya menurut mereka adalah dalam surat al-

37 Antara lain kitab-kitab ushul fikih dari kalangan kaum Sy'ah ialah al-Kafiy oleh Ja'far Muhammad ibn Ya'qub al-Khulainy, al-Tabzib dan al-I'tibar oleh Muhammad ibn Hasan. Sedangkan kitab-kitab dalam bidang fikih antara lain al Mukbtasharu al-Nafi' oleh Abi Qasim al-Husain al-Huliy, Syara'i al-Islam oleh Ja'far al-Hasan al-Huliy, dan Jawahir al-Kalam oleh Muhammad al-Najafiy, Tarkirah al Fuqaba oleh Muhsin Ibn Yusuf al-Huliy, Miftah al-Karamah oleh Muhammad alJawad Ibn Muhammad al-Husein, serta Washail al-Syi'ah ila Masail al-Syariab oleh Muhammad al-Hasan ibn Ali Huri. Lihat, Huzaemah Tahido Yanggo, Pengantar Perbandingan..., hlm. 148-149, dan Muh. Zuhri, Hukum Islam dalam..., hlm. 61 dan 63 356
Muh. Said HM., Doktrin Syi'ah dalam Masalah Imamah dan Fikihnya

Nisa' ayat 24. Sebagian pemimpin mereka memahaminya dari maksud ayat tersebut, bahwa tidak termasuk golongan kami orang yang tidak menghalalkan muth'ah".

6. Kaum wanita hanya berhak menerima warisan benda bergerak, tidak mendapat bagian warisan tana atau benda tak bergerak.

7. Waktu shalat itu 3 (tiga), yaitu pertama Zhuhur dan 'ashar (dikerjakan sekaligus pada waktu Zhuhur atau 'ashar). Kedua, Maghrib dan 'Isya' (dikerjakan sekaligus pada waktu Maghrib atau 'Isya'. Dan ketiga adalah waktu Shubuh.

8. Gadis atau janda boleh menyuruh mengawinkan dirinya, dengan tidak usah izin walinya.

9. Thalak yang diucapkan talak tiga sekaligus, hanya jatuh satu.

10. Shalat Jum'at wajib hukumnya, minimal hanya lima orang jama'ah selain Imam. Dua khuthbah merupakan syarat sah jum'at, dan dilakukan dalam keadaan berdiri.

11. Qashar shalat dalam perjalanan diperbolehkan dengan syarat jarak perjalanan 8 fasakh jalan kaki.

12. Mengharamkan nikah dengan wanita kitabiyah. ${ }^{38}$

\section{Kesimpulan}

Memahami apa yang telah diungkapkan di atas, maka dapat disimpulkan bahwa dalam sejarah awal-awal Islam, masalah imamah menjadi perdebatan sengit di kalangan umat dan para sahabat, terutama ketika Rasulullah Saw wafat. Persoalan serius yang muncu ketika itu sekitar siapa yang bakal menggatikan Rasulullah Saw. dalam kapasitasnya sebagai pemimpin politik, bukan sebagai Nabi Allah, meskipun dalam keyakinan bahwa keduanya menyatu pada diri Rasulullah Saw. Hal tersebut terjadi, karena tidak adanya wasiat dan kejelasan dari Rasulllah Saw. Puncak perdebatan masalah imamah terjadi di akhir hayat Utsman ibn Affan sebagai khalifah ke tiga, selain menyebabkan keter-firqah-an umat, juga pertumpahan darah dan kematian yang tidak dapat terhindarkan. Berbagai tantangan dan

38 Baca, Huzaemah Tahido Yanggo, Ibid, hlm.149, M. Ali Hasan, Perbandingan Marhab..., hlm. 247-248, dan Muh. Zuhri, Hukum Islam dalam..., hlm. 61-62 
Al-Fikra: Jurnal Ilmiah Keislaman, Vol. 8, No. 2, Juli-Desember 2009 pengorbanan yang dialami terutama Ali ibn Abi Thalib dan para pengikut setianya, sebelum ia tampil pada akhirnya sebagai khalifah ke empat menggantikan Utsman ibn Affan dan Ali-pun pada akhirnya, menemui akhir hayatnya oleh ulah kaum khawarij. Pengikut setia Ali ibn Abi Thalib, yang lebih dikenal sebagai kaum Syi'ah (mayoritas Syi'ah dua belas), dalam masalah imamah berkeyakinan, bahwa imamah bukanlah hak setiap orang Islam atau keturunan Quraisy, melainkan hak monopoli Ali ibn Abi Thalib beserta keturunannya. Hukum imamah adalah wajib melalui penetapan nash dan wasiat. Teori politik yang ditawarkan bahwa seorang imam adalah "segalanya" seperti layaknya sebagai seorang Nabi yang wajib ditaati dengan kapasitasnya sebagai pemimpin agama sekaligus sebagai pemimpin politik. Pengangkatannya melalui penetapan nash dan wasiat merupakan kehendak Allah semata, bukan atas kehendak umat manusia. Otoritas politik dan agama berada di tangah Allah, bukan di tangan manusia, karena itu Allah-lah yang menentukan orang yang akan menjadi imam, yang akan melanjutkan risalah Rasul serta memimpin umat manusia. Kepemimpinan seorang imam menurut doktrin Syi'ah, senantiasa memiliki nilai-nilai kebenaran ilahiyah dalam melaksanakan berbagai amanah, sebagai tuntutan dalam penegakan Syari'at. Oleh karena itu selama seorang imam masih hidup dan mampu menjalankan roda pemerintahan Negara, tetap sebagai imam yang wajib ditaati hingga hari wafatnya.

\section{Bibliografi}

Aceh, Abu Bakar, Perbandingan Mazhab, Syiah, Rasionalisme dalam Islam, (Semarang: Ramadhani, 1980).

Hasan, M. Ali, Perbandingan Mą̧hab, edisi 1, (Jakarta: PT. Raja Grafindo Persada, 1995).

Johan, Sudirman M., Politik Keagamaan dalam Islam, edisi 1, (Pekanbaru: Susqa Press, 1995).

Nadwi, Abdul Hasan Ali Al-Hasani An-, Shuratani Mutadhadatani, terjemahan Bey Arifin, dk, (Surabaya: PT. Bina Ilmu, 1988).
Muh. Said HM., Dok.trin Syi'ah dalam Masalah Imamah dan Fikihnya

Nasution, Harun, Islam Ditinjau Dari Berbagai Aspeknya, Jilid I, (Jakarta: UI Press, 1979)

Teologi Islam, Aliran-aliran Sejarah Analisa Perbandingan, edisi 5, (Jakarta: UI Press, 1986).

Nimr, Abdul Mun'im al-, Syi'ah, Imam Mahdi dan Duruz, Sejarah dan Fakta, edisi 1, (t.tp: Qisthi Press, 2003).

Rahmat, Jalaluddin, Islam Alternatif, edisi 1, (Bandung: Mizan, 1986).

Raziq, Ali Abd al-, al-Islam wa Ushul al-Hukmi, ediei 3, (Mesir: Syirkah Syahimah Hadharah, 1925).

Ridha, Muhammad, Al-Imam 'Ali Ibn Aby Thalib, (Beirut: Daar alKutub al-'Ilmiyyah, t.th).

Salus, Ali As-, 'Aqidah al-Imamah inda al-Syi'ab al-Itsna 'Asyariyyah, terjemahan Asmuni Solihan Zamakhsyari, edisi 1, Jakarta: Gema Insan Press, 1997).

Shiddieqy, T.M. Hasbi Ash-, Ilmu Kenegaraan dalam Fiqih Islam, edisi 1, (Jakarta : Bulan Bintang, 1971).

Syahrastani, al-Milal wa al-Nihal, Jilid I , (Cairo: Mushthafa al-Bab alHalabi, 1967).

Syalabi, Ahmad, Mausu'ah (al-Tarekh al-Islami wa al-Hadharah alIslamiyah), Jilid I, edisi VIII, (Mesir: tp. 1978).

Yanggo, Huzaemah Tahido, Pengantar Perbandingan Maz̧ab, edisi 1, (Jakarta: Logos Wacana Ilmu, 1997).

Zahrah, Muhammad Abu, Tarikh al-Mazahib al-Islamiyah, (Cairo: Daar al-Fikr al-Araby, t.th).

Zhahier, Ihsan Ilahi, Al-Syi'ah wa al-Tasyayyu', terjemahan Hafied Salim, edisi 1, (Bandung: PT. Al-Ma'arif, 1984).

Zuhri, Muh., Hukum Islam dalam Lintasan Sejarah, ediai 1, (Jakarta: PT. Raja Grafindo Persada, 1996). 